\title{
Special Issue: Analytic Philosophy of Religion
}

This special number of Manuscrito - Revista Internacional de Filosofia, aims to promote and foster discussion among philosophers, scholars, and the general public alike on a number of central, hotly debated issues in Philosophy of Religion. While "Analytic Philosophy" (broadly construed) is increasingly popular in a number of leading Brazilian Philosophy Departments, Analytic Philosophy of Religion is still at an early stage of development in Brazil, to the extent that this subject is not even considered as an autonomous field of inquiry by public research agencies such as the $\mathrm{CNPq}$, Capes, Fapesp, etc., and that courses in Philosophy of Religion are mostly taught in private and confessional universities. This has led many to wrongly consider this subject as a form of religious apologetics more than to a rigorous philosophical enterprise. The present work aims to challenge and refute this misconception.

In this number of Manuscrito, the reader will find works from both leading and early career scholars discussing a number of issues in Philosophy of Religion, both "classic" (i.e. arguments against and in support of the rationality of Theism, the epistemology of religious beliefs, the problem of evil, etc.) and more contemporary (i.e. the implications of cognitive science in our understanding of religious beliefs, the problem of religious disagreement, formal approaches to Philosophy of Religion, etc,); we aim to show that Philosophy is a vital and rich field of inquiry and debate, which involves and cast new light on a number of metaphysical and epistemological questions, and we are confident that this contribution will lead to a renewed interest in the field.

We would like to thank first and foremost our various contributors and Professor Marco Ruffino, who kindly gave us the opportunity to edit this special number of Manuscrito. 
Moreover, we are extremely grateful to the John Templeton Foundation, for their support of our project "Formal Approaches to Philosophy of Religion and Analytic Theology" (Grant 61108), which resulted in a number of conferences and published works such as this one.

FÁBIO M. BERTATO https://orcid.org/0000-0003-0881-2970 University of Campinas - UNICAMP Centre for Logic, Epistemology, and the History of Science (CLE) Campinas S.P. Brazil fbertato@unicamp.br

Nicola Claudio Salvatore https://orcid.org/0000-0002-7947-6233 Universidade do Vale do Rio dos Sinos Unisinos, Escola de Humanidade Department of Philosophy São Leopoldo, R.S. Brazil nicolaclaudiosalvatore@googlemail.com https://doi.org/10.1590/0100-6045.2020.V44N4.FN

\section{References}

BROŻEK, Bartosz; OLSZEWSKI, Adam; HOHOL, Mateusz (Eds.) Logic in Theology. Cracow: Copernicus Center Press, 2013.

WAINWRIGHT, William (Ed.). The Oxford Handbook of Philosophy of Religion. New York: Oxford University Press, 2005.

\section{$(\mathrm{ccc}) \mathrm{BY}$}

